\title{
The Effect of Personal Protective Equipment Uptake on the Risk of Leprosy in Adults: Meta Analysis
}

\author{
Rizki Kurniawan Saputra' ${ }^{1)}$, Setyo Sri Rahardjo'), Bhisma Murti1) \\ 1)Masters Program in Public Health, Universitas Sebelas Maret \\ 2)Faculty of Medicine, Universitas Sebelas Maret
}

\section{ABSTRACT}

Background: Leptospirosis is an acute infectious disease that can attack humans and animals caused by the Leptospira bacteria. Leptospirosis contributes to morbidity and mortality in the high-risk group, namely adults. Compliance with the use of personal protective equipment and direct contact with animal tissue infected with Leptospira $s p$. bacteria increase the risk of leptospirosis. This study aims to analyze the magnitude of the effect of using personal protective equipment on the risk of leptospirosis with a meta-analysis.

Subjects and Method: This was a systematic review and meta-analysis carried out by following the PRISMA flow diagram. The process of searching for articles is through a journal database which includes: PubMed, Springer Link, Google Scholar and Science Direct by selecting articles published in 1999-2020. Keywords used "Leptospirosis AND Personal Protective Equipment", "leptospirosis" AND "risk factors", "leptospirosis AND adjusted odds ratio", "leptospirosis" AND "adults", "leptospirosis AND risk factors AND adjusted odds ratio". The inclusion criteria were full paper articles with observational study design, articles in English and Indonesian, multivariate analysis used with adjusted odds ratio. Articles that meet the requirements are analyzed using the Revmen 5.3 application.
Results: A total of 8 articles were reviewed in this study with a cross-sectional and case-control study design. Meta-analysis of 4 case-control studies showed that non-adherence to the use of personal protective equipment had a 2.77 times increased risk of leptospirosis compared with using personal protective equipment $(\mathrm{aOR}=2.77$, $95 \% \mathrm{CI}=1.76$ to 4.36 , $\mathrm{p}<0.001$ ). A meta-analysis of 4 cross-sectional studies concluded that nonadherence to the use of personal protective equipment had a 2.73 times increased risk of leptospirosis compared with using personal protective equipment $(\mathrm{aOR}=2.73,95 \% \mathrm{CI}=1.99$ to $3.74 ; \mathrm{p}=$ $<0.001)$.

Conclusion: Non-compliance with the use of personal protective equipment increases the risk of leptospirosis.

Keywords: leptospirosis, personal protective equipment, meta-analysis

\section{Correspondence:}

Rizki Kurniawan Saputra. Masters Program in Public Health, Universitas Sebelas Maret. Jl.Ir. Sutami 36A, Surakarta 57126, Central Java. Email: rizkikurniawansaputra@gmail.com. Mobile: 087738152955 .

\section{Cite this as:}

Saputra RK, Rahardjo SS, Murti B (2021). The Effect of Personal Protective Equipment Uptake on the Risk of Leprosy in Adults: Meta Analysis. J Health Promote Behav. 06(01): 21-31. https://doi.org/10.26911/thejhpb.2021.06.01.03.

c. J) Journal of Health Promotion and Behavioris licensed under a Creative Commons Journal of Health Promotion and Behavioris licensed under a Creative
Attribution-NonCommercial-ShareAlike 4.o International License.

\section{BACKGROUND}

Leptospirosis is an acute infectious disease that can attack humans and animals (zoonosis) caused by the Leptospira bacteria. Countries with subtropical and tropical climates around the world that have high rain intensity have a high potential for the spread of leptospirosis and become a serious public health problem (WHO, 2003). Leptospirosis is an endemic infectious disease. This type of disease is neglected or 
Neglected Infectious Diseases (NIDs), its existence is widespread throughout the world except the arctic regions (Rusmini, 2011).

Each year there are more than 500,000 cases of leptospirosis worldwide, with a Case Fatality Rate (CFR) $<5 \%$ to $30 \%$. Significantly, the incidence of leptospirosis is also more common in tropical climates, which ranges from $10-100$ incidents per 100,000 population per year, while for sub-tropical countries it is around 0.1-1 incidence per 100,000 population per year (WHO, 2011).

Leptospirosis can show various clinical manifestations, from mild leptospirosis to severe leptospirosis such as fever, chills, headache, malaise, vomiting, conjunctivitis (conjunctival suffusion), and pain in the muscles, especially the calf muscles (pain in the gastrocnemius area) and back muscles. This disease can attack organs such as the kidneys, brain, liver, uterus and eyes (WHO, 2003).

The people with the greatest risk of contracting leptospirosis are people who live in urban slum areas and farm laborers and livestock raisers in rural areas. Someone who has a habit of doing activities in lakes or rivers, such as swimming, also has a similar threat. The existence of standing water and the habit of bathing or washing in the river has a 4 to 7 times higher risk of developing leptospirosis because the river is polluted, especially from garbage where there are carcasses of rats in the river infected with leptospira (Riyaningsih, 2012).

The existence of vectors with high rodent populations and poor environmental sanitation conditions and slums due to flooding are the factors that cause leptospirosis cases. Based on the aspect of the cause, leptospirosis is a bacterial zoonosis, whereas from the transmission aspect, leptospirosis is one of the direct zoonoses (host to host transmission) because transmission only requires one vertebrate (Ministry of Health, 2017).

The use of personal protective equipment (PPE) is one of the precautions that can be done to reduce the risk of leptospirosis. Personal protective equipment (PPE) is used when working and doing activities according to work hazards and risks to maintain the safety of the workers themselves and those around them. Efforts to use personal protective equipment occupy the last level of prevention, but the application of personal protective equipment is highly recommended (Yulita, 2019). The habit of walking without footwear or personal protective equipment is also a risk factor for leptospirosis (Desvars et al, 2013). In addition, the type of work, life habits, climate and environment also affect the number of cases and the prevalence of leptospirosis (Victoriano et al, 2009).

Several primary studies have shown mixed results regarding the risk factors that most influence the incidence of leptospirosis. Risk factors for leptospirosism transmission include the presence of cuts or abrasions on the skin, daily living habits (disobedience to use personal protective equipment when working or doing activities and frequently crossing stagnant water), contact with rats or rat urine, and contact with other infected animal tissues. Leptospira (Sambasiva et al, 2003). The purpose of this study was to analyze the risk factors for leptospirosis in adults in various countries so that a summary of studies with mixed results that have been conducted can be obtained.

\section{SUBJECTS AND METHOD}

\section{Study Design}

This was a meta-analysis research. Search for articles was carried out for one month 
systematically through PubMed, Springer Link, Google Scholar, and Science Direct databases. Key words used: "Leptospirosis AND Personal Protective Equipment", "leptospirosis" AND "risk factors", "leptospirosis AND adjusted odds ratio", "leptospirosis" AND "adults", "leptospirosis AND risk factors AND adjusted odds ratio".

\section{Inclusion Criteria}

The author developed the inclusion criteria, namely articles in English and in Indonesian, full text with a cross-sectional casecontrol study design. Research subjects were women and men aged (26-65 years) who suffered from leptospirosis based on laboratory test results or from medical records. The analysis used multivariate with adjusted odds ratio and outcomes was the incidence of leptospirosis.

\section{Exclusion Criteria}

The exclusion criteria in this study were a randomized control trial (RCT), a quasi experiment, study protocols, and non-full text. Published articles are not using English or Indonesian language, not a multivariate analysis study, and does not include the adjusted Odds Ratio (aOR).

\section{Operational Definition of Variables} The article search was carried out by considering the eligibility criteria defined using the PICO model. The population in the study were women and men aged (26-65 years) with intervention in the form of noncompliance using personal protective equipment. Comparison, namely falling using personal protective equipment. Outcome was the incidence of leptospirosis.

Leptospirosis is a zoonotic disease caused by the Leptospira bacteria which can attack organs such as the kidneys, brain, liver, uterus and eyes. Severe and mild clinical symptoms such as fever, headache, muscle pain, especially in the calf, thigh, and kidney failure. Leptospirosis is transmitted by contact with water, mud, plants that have been contaminated by urine from rodents (rats) and other animals that contain Leptospira bacteria.

Personal protective equipment is defined as equipment that is used when working or doing activities according to hazards and risks to maintain the safety of oneself and those around them. Examples of personal protective equipment such as footwear (sandals or shoes), gloves, masks, long-sleeved clothing, and head protection. The use of personal protective equipment can be completely used, one or several types at once.

\section{Data Analysis}

Articles are identified using the PRISMA diagram, and analyzed using the Review Manager 5.3 application by calculating the effect size and heterogeneity to determine the research model that is combined and forms the final meta-analysis result.

\section{RESULTS}

The process of reviewing articles can be seen in Figure 1. The PRISMA diagram This meta-analysis analyzes 8 primary studies conducted in the America, Asia, Africa, Europe.

The study quality assessment was carried out quantitatively. This research was conducted using an assessment of the quality of research studies for the design of Case Control Center for Evidence Based Management (CEBMa) and cross sectional Center for Evidence Based Management (CEBMa) in 2014. 
Saputra et al./ Personal Protective Equipment Uptake on the Risk of Leprosy in Adults

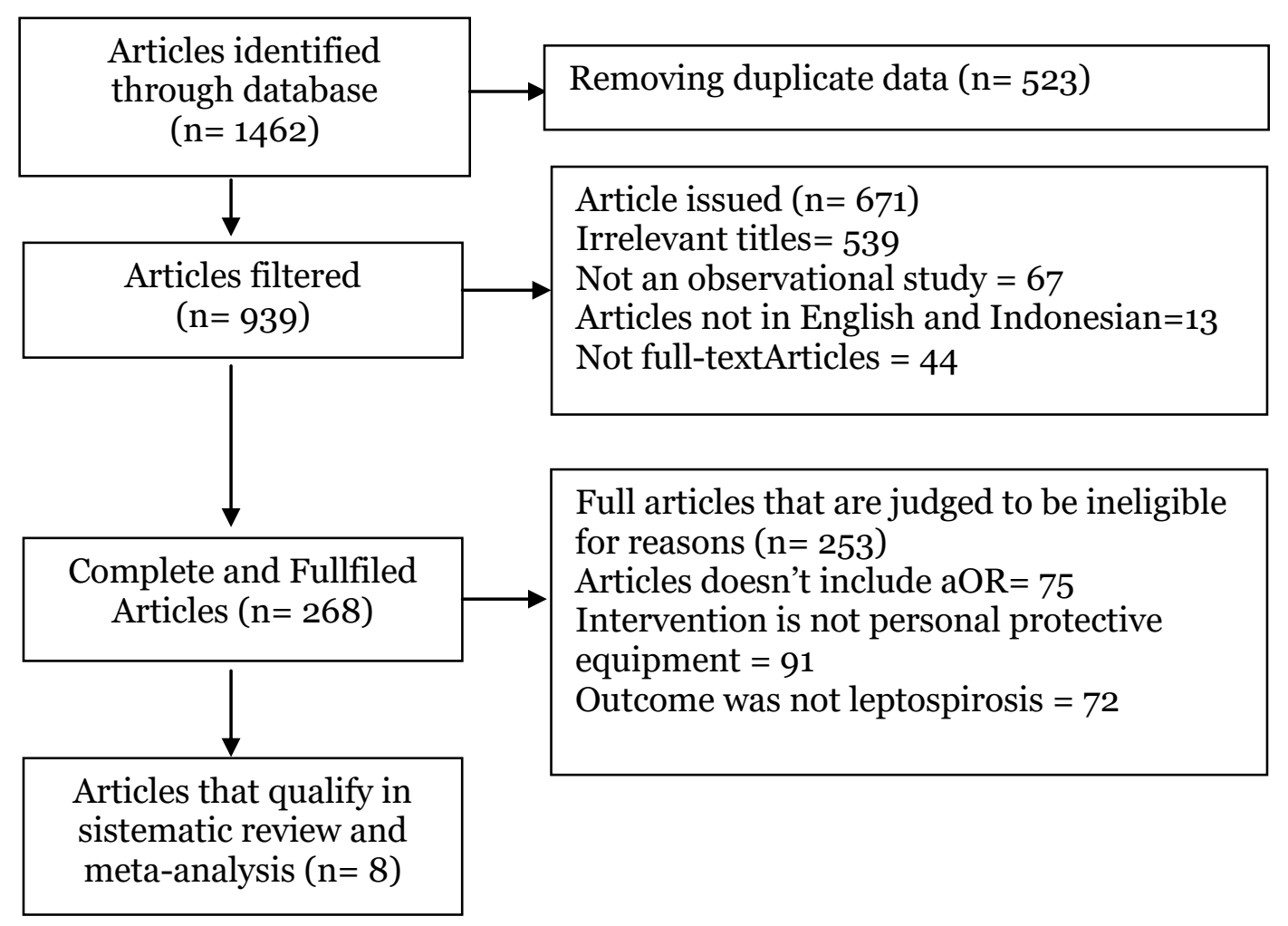

Figure 1. PRISMA Diagram

\section{a. Forest plot}

The effect between the use of personal protective equipment and the incidence of

leptospirosis is shown in the forest plot results in Figure 2.

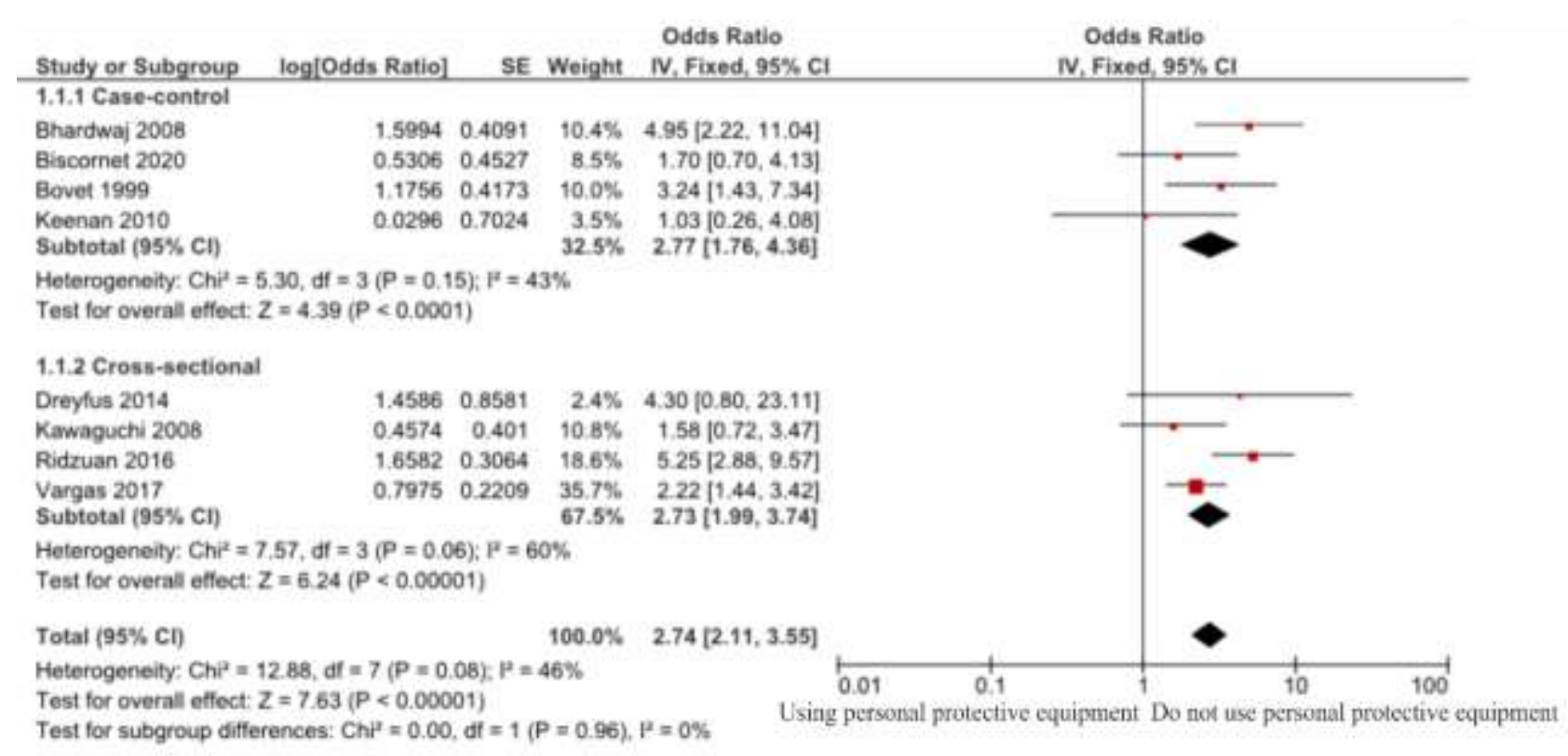

Figure 2. Forest plot the effect of using personal protective equipment on the risk of leptospirosis 
Table 1. Research Quality Assessment Case control studies

\begin{tabular}{|c|c|c|c|c|c|c|c|c|c|c|c|c|c|}
\hline \multirow{2}{*}{ Primary Study } & \multicolumn{13}{|c|}{ Criteria } \\
\hline & $\mathbf{1}$ & 2 & 3 & 4 & 5 & 6 & 7 & 8 & 9 & 10 & $\mathbf{1 1}$ & 12 & Total \\
\hline Biscornetet al. (2020) & 1 & 1 & 1 & 1 & 1 & 1 & O & 1 & 1 & 1 & 0 & 1 & 10 \\
\hline Keenanet al. (2010). & 1 & 1 & 1 & 1 & 1 & 1 & $\mathrm{O}$ & 1 & 1 & 1 & $\mathrm{O}$ & 1 & 10 \\
\hline Bhardwajet al(2008). & 1 & 1 & 1 & 1 & 1 & 1 & $\mathrm{O}$ & 1 & 1 & 1 & $\mathrm{O}$ & 1 & 10 \\
\hline Bovetet al. (1999). & 1 & 1 & 1 & 1 & 1 & 1 & $\mathrm{O}$ & 1 & 1 & 1 & $\mathrm{O}$ & 1 & 10 \\
\hline
\end{tabular}

Table 2. Research Quality Assessment Cross sectional Study

\begin{tabular}{|c|c|c|c|c|c|c|c|c|c|c|c|c|c|}
\hline \multirow{2}{*}{ Primary Study } & \multicolumn{13}{|c|}{ Criteria } \\
\hline & $\mathbf{1}$ & 2 & 3 & 4 & 5 & 6 & 7 & 8 & 9 & 10 & 11 & 12 & Total \\
\hline Kawaguchi et al. (2008) & 1 & 1 & 1 & 1 & 1 & 1 & 0 & 1 & 1 & 1 & 0 & 1 & 10 \\
\hline Ridzuanet al. (2016). & 1 & 1 & 1 & 1 & 1 & 1 & $\mathrm{O}$ & 1 & 1 & 1 & O & 1 & 10 \\
\hline Dreyfus et al.(2014). & 1 & 1 & 1 & 1 & 1 & 1 & o & 1 & 1 & 1 & 0 & 1 & 10 \\
\hline Vargaset al. (2017). & 1 & 1 & 1 & 1 & 1 & 1 & $\mathrm{O}$ & 1 & 1 & 1 & $\mathrm{O}$ & 1 & 10 \\
\hline
\end{tabular}

Tabel 3. Deskripsi penelitian primer yang dimasukkan dalam meta-analisis

\begin{tabular}{|c|c|c|c|c|c|c|c|}
\hline $\begin{array}{c}\text { Author } \\
\text { (Year) }\end{array}$ & Country & $\begin{array}{c}\text { Study } \\
\text { Design }\end{array}$ & Sample & $\begin{array}{c}\mathbf{P} \\
\text { Population }\end{array}$ & $\begin{array}{c}\text { I } \\
\text { Intervention } \\
\end{array}$ & $\begin{array}{c}\text { C } \\
\text { Comparison }\end{array}$ & $\begin{array}{c}\text { O } \\
\text { Output }\end{array}$ \\
\hline $\begin{array}{l}\text { Biscornet et } \\
\text { al. (2020) }\end{array}$ & Seychelles & $\begin{array}{l}\text { Case } \\
\text { Control }\end{array}$ & 219 & $\begin{array}{l}\text { Leptospirosis confirmed } \\
\text { patients with a mean age } \\
\text { of } 36 \text { years }\end{array}$ & $\begin{array}{l}\text { Do not use complete personal } \\
\text { protective equipment as } \\
\text { protection }\end{array}$ & $\begin{array}{l}\text { Use complete personal } \\
\text { protective equipment as } \\
\text { protection }\end{array}$ & $\begin{array}{l}\text { Leptospirosis } \\
\text { disease }\end{array}$ \\
\hline $\begin{array}{l}\text { Keenan et } \\
\text { al. (2018) }\end{array}$ & Jamaica & $\begin{array}{l}\text { Case } \\
\text { Control }\end{array}$ & 89 & $\begin{array}{l}\text { Leptospirosis confirmed } \\
\text { patients with a mean age } \\
\text { of } 38 \text { years }\end{array}$ & $\begin{array}{l}\text { Walking and doing activities } \\
\text { without using personal } \\
\text { protective equipment (footwear) }\end{array}$ & $\begin{array}{l}\text { Walk and do activities } \\
\text { using personal protective } \\
\text { equipment (footwear) }\end{array}$ & $\begin{array}{l}\text { Leptospirosis } \\
\text { disease }\end{array}$ \\
\hline $\begin{array}{l}\text { Bhardwaj et } \\
\text { al. (2008) }\end{array}$ & India & $\begin{array}{l}\text { Case } \\
\text { Control }\end{array}$ & 62 & $\begin{array}{l}\text { The patients confirmed } \\
\text { leptospirosis with a mean } \\
\text { age of } 29 \text { years }\end{array}$ & $\begin{array}{l}\text { Walking and doing activities } \\
\text { without using personal } \\
\text { protective equipment (footwear) }\end{array}$ & $\begin{array}{l}\text { Walk and do activities } \\
\text { using personal protective } \\
\text { equipment (footwear) }\end{array}$ & $\begin{array}{l}\text { Leptospirosis } \\
\text { disease }\end{array}$ \\
\hline $\begin{array}{l}\text { Bovet et al. } \\
\text { (1999) }\end{array}$ & India & $\begin{array}{l}\text { Case } \\
\text { Control }\end{array}$ & 75 & $\begin{array}{l}\text { The patient was diagnosed } \\
\text { with leptospirosis }\end{array}$ & Walk barefoot & Walk in footwear & $\begin{array}{l}\text { Leptospirosis } \\
\text { disease }\end{array}$ \\
\hline $\begin{array}{l}\text { Kawaguchi } \\
\text { et al. (2008) }\end{array}$ & Laos & $\begin{array}{l}\text { Cross } \\
\text { Sectional }\end{array}$ & 406 & $\begin{array}{l}\text { Leptospirosis confirmed } \\
\text { patients with a mean age } \\
\text { of } 35 \text { years }\end{array}$ & Walk barefoot & Walk in footwear & $\begin{array}{l}\text { Leptospirosis } \\
\text { disease }\end{array}$ \\
\hline $\begin{array}{l}\text { Ridzuan et } \\
\text { al. (2016) }\end{array}$ & Malaysia & $\begin{array}{l}\text { Cross } \\
\text { Sectional }\end{array}$ & 350 & $\begin{array}{l}\text { Oil palm plantation } \\
\text { workers infected with }\end{array}$ & $\begin{array}{l}\text { Work not using personal } \\
\text { protective equipment (hand }\end{array}$ & $\begin{array}{l}\text { Work using personal } \\
\text { protective equipment }\end{array}$ & $\begin{array}{l}\text { Leptospirosis } \\
\text { disease }\end{array}$ \\
\hline
\end{tabular}




\begin{tabular}{|c|c|c|c|c|c|c|c|}
\hline $\begin{array}{c}\text { Author } \\
\text { (Year) }\end{array}$ & Country & $\begin{array}{c}\text { Study } \\
\text { Design }\end{array}$ & Sample & $\begin{array}{c}\mathbf{P} \\
\text { Population }\end{array}$ & $\begin{array}{c}\text { I } \\
\text { Intervention }\end{array}$ & $\begin{array}{c}\mathrm{C} \\
\text { Comparison }\end{array}$ & $\begin{array}{c}\text { O } \\
\text { Output }\end{array}$ \\
\hline & & & & $\begin{array}{l}\text { leptospirosis have an } \\
\text { average age of } 31 \text { years }\end{array}$ & protection) & (hand protection) & \\
\hline $\begin{array}{l}\text { Dreyfus et } \\
\text { al. (2014) }\end{array}$ & $\begin{array}{l}\text { New } \\
\text { Zealand }\end{array}$ & $\begin{array}{l}\text { Cross } \\
\text { Sectional }\end{array}$ & 567 & $\begin{array}{l}\text { Slaughterhouse workers } \\
\text { infected with leptospirosis }\end{array}$ & $\begin{array}{l}\text { Never or occasionally use masks } \\
\text { and protective goggles }\end{array}$ & $\begin{array}{l}\text { Often or always use masks } \\
\text { and protective glasses }\end{array}$ & $\begin{array}{l}\text { Leptospirosis } \\
\text { disease }\end{array}$ \\
\hline $\begin{array}{l}\text { Vargas et al. } \\
\text { (2019) }\end{array}$ & Colombia & $\begin{array}{l}\text { Cross } \\
\text { Sectional }\end{array}$ & 353 & $\begin{array}{l}\text { Leptospirosis confirmed } \\
\text { patients with a mean age } \\
\text { of } 41 \text { years }\end{array}$ & Walk barefoot & Walk in footwear & $\begin{array}{l}\text { Leptospirosis } \\
\text { disease }\end{array}$ \\
\hline
\end{tabular}

\section{b. Funnel plot}

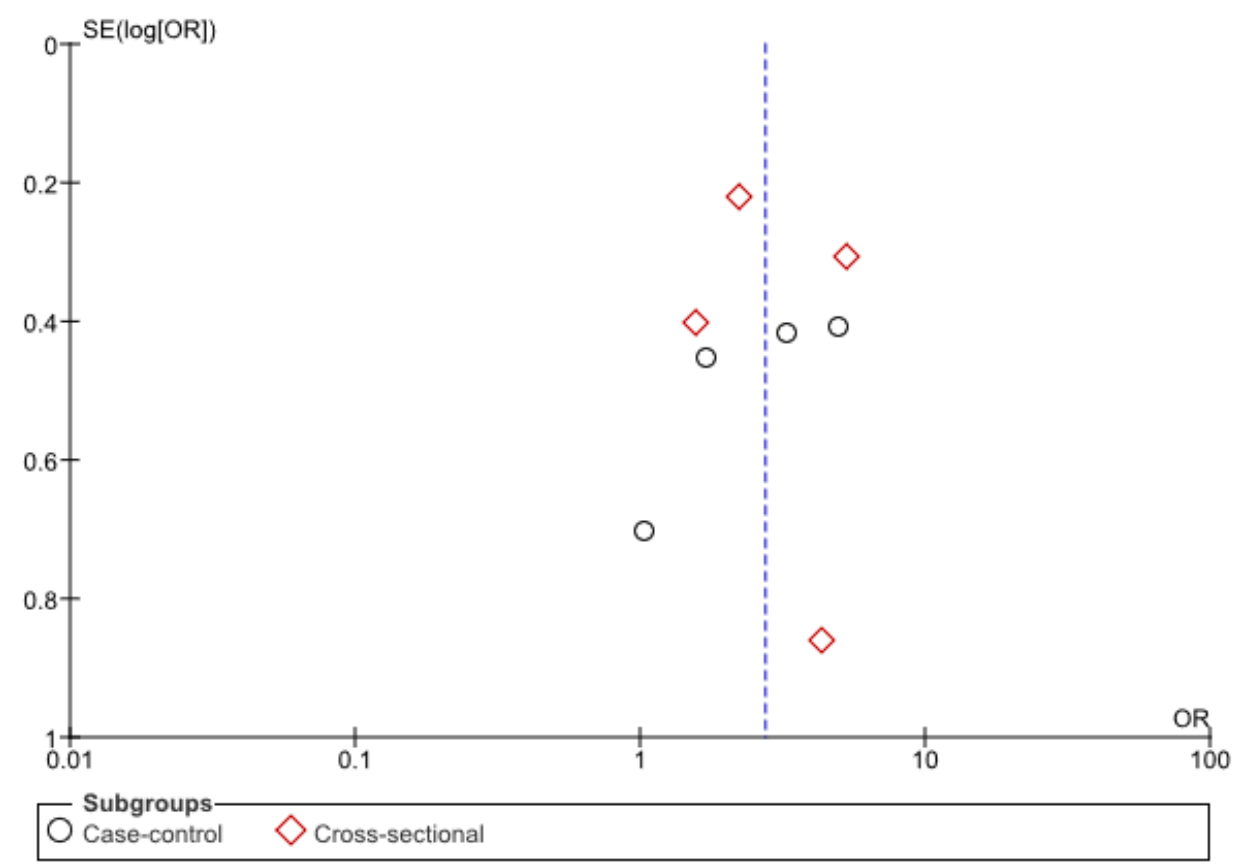

Figure 3. Funnel plot of the effect of using personal protective equipment on the risk of leptospirosis 

Saputra et al./ Personal Protective Equipment Uptake on the Risk of Leprosy in Adults

Figure 3 shows that there is no publication bias due to the symmetrical distribution of the plot.

Interpretation of the results from the meta-analysis process can be seen from the forest plot. Figure 3 case-control study shows that not using personal protective equipment increases the incidence of leptospirosis by 2.77 times compared to using personal protective equipment $(\mathrm{aOR}=2.77$, 95\% CI $=1.76-4.36, \mathrm{p}<0.001)$ and 4 crosssectional studies show that no using personal protective equipment increased the incidence of leptospirosis 2.73 times compared to using personal protective equipment $(\mathrm{aOR}=2.73,95 \% \mathrm{CI}=1.99$ to $3.74, \mathrm{p}$ $<0.001)$. The heterogeneity of the research data shows $I^{2}=46 \%$ so that the data distribution is stated to be homogeneous (fixed effect model).

The funnel plot in Figure 3 shows that there is no publication bias due to the plotymetric distribution. On the left side of the diagram there are 4 plots with standard errors between 0.2 and 0.8 . On the right side there are 4 plots with standard errors between 0.2 and 1 .

\section{DISCUSSION}

This study is a systematic review and metaanalysis taking the topic of risk factors that cause leptospirosis in adult men and women aged 26-65 years. The factor used as an independent variable in this study is the use of personal protective equipment. The outcome which became the dependent variable in this study was the incidence of leptospirosis. Research with the aim of knowing the magnitude of the effect of the use of personal protective equipment used a meta-analysis study design.

The primary research results used for meta-data analysis were collected from various countries and in a large sample size, so as to increase the heterogeneity of rese- arch results. In addition, the meta-analysis research process has gone through the PRISMA stage which is a series of processes for identifying articles using database searches, filtering articles by determining inclusion and exclusion criteria, assessing the feasibility of primary studies and selecting articles used for meta-analysis.

Articles that have been compiled through database searches are then included in the Mendeley program to make identification easier. This study collected 1,462 articles in the early stages of the PRISMA process. Subsequently, 523 articles were deleted. 939 articles that have been filtered are then reissued using the criteria determined by the researcher. The exclusion criteria determined by the researcher were descriptive articles/systematic review/ metaanalysis, did not have PDF files, research titles were irrelevant, articles were not full text and articles did not use a case control or cross sectional study design.

The exclusion of articles at this stage were 671 files. Furthermore, articles that had complete data were 268, the exclusion process was carried out again with the criteria for a sample of non-women and adult men, case control and cross-sectional studies did not include aOR values and the study outcome was not the incidence of leptospirosis. The results of the second exclusion were 253 articles, so the articles to be used for the meta-analysis were 8 articles. The quality of 8 articles was assessed using the 2014 CEBMa Critical Appraisal Checklist specifically for case control and cross sectional studies.

Primary articles that have met the requirements are then analyzed using the Review Manager 5.3 program. Data analysis was carried out one by one to find out the influence of the use of personal protective equipment on the risk of leptospirosis. 


\section{Effect of use of personal protective equipment on the risk of leptospiro- sis in adults}

The primary research used in the metaanalysis was 8 articles from Jamaica, India, Laos, Malaysia, Seychelles, Colombia and New Zealand. The study design was an observational case control and cross sectional study. Analyzes were performed with each subgroup of observational study designs. The results of the case-control study subgroup meta-analysis showed that not using personal protective equipment increased the risk of leptospirosis by 2.77 times compared to those using personal protective equipment $(\mathrm{aOR}=2.77,95 \% \mathrm{CI}=$ 1.76-4.36, p <0.001). Meanwhile, a crosssectional study using subgroup analysis showed that not using personal protective equipment increased the risk of leptospirosis by 2.73 times compared to using personal protective equipment $(\mathrm{aOR}=2.73$, 95\% CI $=1.99-3.74, \mathrm{p}<0.001)$.

The use of personal protective equipment is important and needs to be considered for use, especially when working or doing activities outside the home. Leptospira bacteria have the potential to easily enter the patient's body if the feet, hands or body parts are not properly protected. Personal protective equipment will provide adequate protection if the protective equipment is chosen appropriately and comfortably when worn by the worker concerned (Buntarto, 2015).

The risk of humans becoming infected depends on exposure to risk factors. Some humans are at high risk of exposure to leptospirosis because of their work, the environment in which they live or their lifestyle. The main occupational groups at risk are farmers or plantation workers, pet shop clerks, ranchers, sewer cleaners, slaughter workers, meat processors, and the military. Humans can become infected with leptospirosis due to direct or indirect contact with the urine of animals infected with Leptospira. The habit of walking without footwear or personal protective equipment is also a risk factor for leptospirosis (Desvars et al, 2013). In addition, the type of work, life habits, climate and environment also affect the number of cases and the prevalence of leptospirosis (Victoriano et al, 2009).

Other groups that have a high risk of being infected with leptospirosis are areas or populations affected by natural disasters such as floods and an increase in the number of people who engage in recreational water sports. Not using personal protective equipment (footwear) increases the risk of leptospirosis 4.59 times $(\mathrm{aOR}=$ $4.95,95 \% \mathrm{CI}=2.22$ to $11.06, \mathrm{p}<0.001)$ in the city of Surat, India during flooding (Bhardwaj et al, 2008).

Non-compliance with the use of personal protective equipment can affect the risk of leptospirosis caused by the leptospira bacteria that can enter the patient's body tissue through wounds on the skin or mucous membranes. Leptospira sp. Bacteria. those that successfully infect humans, will enter the circulatory system, then spread to various organs and reproduce, especially in the liver, kidneys and mammary glands and the lining of the brain (Faine et al, 1999).

Exposure to standing water from rice fields when experiencing skin scratches or wounds, washing your face with other water sources such as springs, flowing river water, and pond water are not recognized as risk factors for leptospirosis. From the independent variables studied as a preventive factor, only wearing personal protective equipment (boots) when exposed to a puddle of rice field $(\mathrm{OR}=0.07,95 \% \mathrm{CI}=0.02, \mathrm{p}=$ o.22) had a significant impact on reducing 
Saputra et al./ Personal Protective Equipment Uptake on the Risk of Leprosy in Adults

the risk of leptospirosis (Sahneh et al, 2019).

\section{AUTHOR CONTRIBUTION}

Rizki Kurniawan Saputra is the principal researcher who selects topics, explores and collects research data. Setyo Sri Rahardjo and Bhisma Murti played a role in analyzing data and reviewing research documents.

\section{CONFLICT OF INTEREST}

There is no conflict of interest in this study.

\section{FUNDING AND SPONSORSHIP}

This study is self-funded.

\section{ACKNOWLEDGEIMENT}

We are especially grateful to the database providers PubMed, Google Scholar, Science Direct and Springer Link.

\section{REFERENCE}

Bhardwaj P, Kosambiya JK, Desai VK (2008). A case control study to explore the risk factors for acquisition of leptospirosis in Surat city, after flood. Indian J Med Sci. 62(11):431-438. doi: 10.4103/0019-5359.48454.

Buntarto (2015). Panduan praktis keselamatan \& kesehatan kerja (1st ed.) (Practical guide to occupational safety \& health (1st ed)). Yogyakarta: Pustaka Baru Press.

Desvars A, Michault A, Bourhy P (2013). Leptospirosis in the western Indian Ocean islands: what is known so far?. Vet Res, 44(80):1-11. https://doi.org/10.1186/1297- 9716-44-80.

Faine S, Adler B, Bolin C, Perolat P (1999). Leptospira and Leptospirosis (2nd ed.). Melbourne: MediSci Press.

Kemenkes RI (2017). Petunjuk teknis pengendalian leptospirosis (Cetakan Ke-3; Direktorat P2P, ed.). Jakarta.
Riyaningsih R, Hadisaputro S, Suhartono S (2012). Faktor risiko lingkungan kejadian leptospirosis di Jawa Tengah (Studi kasus di Kota Semarang, Kabupaten Demak dan Pati) (Environmental risk factors for leptospirosis in Central Java (Case study in Semarang City, Demak and Pati District)). Jurnal Kesehatan Lingkungan Indonesia. 11(1):87-94. https://doi.org/10.14710/jkli.11.1.87-94.

Rusmini (2011). Bahaya Leptospirosis (Penyakit kencing tikus) \& cara pencegahannya (S. Handayani, ed.) (The dangers of leptospirosis (Rat urinary Disease) \& how to prevent it. Yogyakarta: Gosyen Publishing.

Sahneh E, Delpisheh A, Sayehmiri K, Khodabakhshi B, Moafi-Madani M (2019). Investigation of risk factors associated with leptospirosis in the North of Iran (2011-2017). J Res Health Sci. PMID: 31278217.

Sambasiva RR, Naveen G, Bhalla P, Agarwal SK (2003). Leptospirosis in India and the rest of the world. Braz J Infect Dis 2003. 7(3):178-193. https://doi:10.1590/s1413-86702003000300003.

Victoriano AFB, Smythe LD, Gloriani-Barzaga $\mathrm{N}$, et al. (2009) Leptospirosis in the Asia Pacific region. BMC Infect Dis. (9)147.https://doi.org/10.1186/1 471-2334-9-147.

World Health Organization (2003). Human Leptospirosis; Guidance for Diagnosis, Surveillance and Control. Malta: WHO Library Cataloguing-in-Publication Data.

World Health Organization. (2011). Weekly Epidemiological Record, Geneva.

Yulita I, Widjasena B, Jayanti S (2019). Faktor yang berhubungan dengan disiplin penggunaan alat pelindung diri pada penyapu jalan di Kota Sema- 
Saputra et al./ Personal Protective Equipment Uptake on the Risk of Leprosy in Adults

rang (Factors related to the discipline of using personal protective equipment on street sweepers in Semarang City). Jurnal Kesehatan Masyarakat
(Undip). 7(1): 330-336. Retrieved from https://ejournal3.undip.ac.id/index.php/jkm/article/view/22995. 